Western University

Scholarship@Western

Department of Economics Research Reports

Economics Working Papers Archive

1977

\title{
The Intergenerational Distribution of the Gains from Technical Change and from International Trade
}

Joel Fried

Follow this and additional works at: https://ir.lib.uwo.ca/economicsresrpt

Part of the Economics Commons

Citation of this paper:

Fried, Joel. "The Intergenerational Distribution of the Gains from Technical Change and from International Trade." Department of Economics Research Reports, 7712. London, ON: Department of Economics, University of Western Ontario (1977). 


\section{RESEARCH REPORT 7712}

The Intergenerational Distribution of the

Gains from Technical Change and from

International Trade

by

Joel Fried*

November 1977

\footnotetext{
* I would like to gratefully acknowledge my indebtedness to Peter Howitt for both his help and encouragement. I would also like to thank the members of the University of Western Ontario Money and Trade Workshop for helpful comments on. earlier versions of this paper. Any errors that remain are the author's.
} 


\begin{abstract}
This paper argues that, in an overlapping generations model, an income increasing innovation may cause all agents born after the innovation to have lower welfare than agents living prior to it despite having the same tastes and life cycle endowments. Thus, in the long run, free trade in commodities may make everyone in a country worse off. Further, compensation for losses becomes more difficult, requiring current transfers for past innovations and future transfers for current innovations. It is also shown that the young in debtor countries have a preference for portfolio autarky, that tariffs will alter the debtor position of a country and that a majority vote mechanism for choosing tariff levels may be intertemporally unstable.
\end{abstract}


The Intergenerational Distribution of the Gains from Technical Change and from International Trade

It has long been recognized that agents holding different endowments will be affected differently by an innovation that alters relative prices. Thus a move to a Pareto-efficient equilibrium may cause some agents to have a reduced level of welfare. Despite this fact, Pareto-efficiency has become virtually a sine qua non in evaluating the welfare implications of theoretical constructs and in making policy recommendations. It is, either implicitly or explicitly, assumed that the distribution problem associated with any change in the economic environment can somehow be worked out in moving to a potentially superior environment through lump sum transfers. This paper addresses the issue of how a change in the environment affects the intergenerational distribution of welfare when such transfers are not made. The point that is stressed is that an innovation that could make everyone, now and in the future, better off may worsen the level of welfare for al1 agents born after the innovation despite the fact that they have the same tastes and the same life cycle endowments as those agents who instituted the innovation. In other words, if individuals are finite lived, then the gains associated with a move to a market determined, Paretoefficient equilibrium may only be transitory, accruing entirely to (some of) those alive at the time of the innovation.

This result appears puzzling for it means that those generations with the larger lifetime income will have the lower level of welfare. The reason for this paradoxical result revolves around how endowments are distributed at the time of the innovation: At that moment future generations own only their (potentia1) human capital. That, in e̊quilibrium, their lifetime ownership of non-human factors of production will be the same as their predecessors says 
nothing about the terms at which titles to those factors are obtained. If, because of the innovation, the prices of these titles--and therefore the equilibrium rate of interest--are sufficiently changed, it may so alter the consumption profile that welfare falls because of diminishing marginal utility despite the fact that total lifetime consumption increases. For future generations to be made better off by some income increasing innovation, the wage rate must rise and/or the price of titles to other factors must fall sufficiently far so that not all the increase in non-human rental income is captured by the initial owners of those assets. There is no assurance that these circumstances will generally hold.

Section II sets out the overlapping generations framework and in section III the effects of a labour-saving technical innovation on the intergenerational distribution of welfare are examined. The next section uses a specific example to consider the distribution of the gains from international trade among generations. The application of the analysis to international trade is important because the factor price effects of opening an economy to trade cause wages in at least one country to fall, a necessary precondition for future generations to be made worse off, whereas, empirically, labour saving technical innovations appear to be the exception rather than the rule. Section $\mathrm{V}$ continues the examination of international trade, this time when titles to factors of production as well as consumption goods can be internationally traded. It is shown that it is neither a necessary nor sufficient condition that a nation not be a debtor for future generations to gain from trade. However, if an individual cannot borrow on his human capital, future generations would always prefer a trading regime that did not permit trade in titles to other factors of production to a trading regime where the country was a net debtor. Section VI makes some concluding remarks about the likely permanence of an innovation that reduces the welfare of future generations 。 
II The Conceptual Framework

The conceptual framework used is an overlapping generations model, (c.f. Samuelson (1958)). To pose the issues involved in their starkest form it is assumed that population is constant at the level $\mathrm{N}$, that the population in each generation is the same as in any other and that each agent lives only two periods. ${ }^{1}$ Thus the population of each generation is $N / 2$. Further all agents, whatever their generation, are assumed to have identical tastes.

An agent is born owning only his labour endowment. This endowment consists of two units of labour, one supplied in each period of his life. Each member of each generation is similarly endowed. During the first period of his life he earns income from supplying his labour unit at a competitive wage, w, measured in units of some numeraire good, and with the proceeds he either consumes output or saves by purchasing an asset costing $P_{\&}$ per unit. A young agent (i.e., one in the first period of his life) may borrow by going short in assets, but the value of this dissaving cannot be greater than the present value of his labour income in the second period. An old agent (one in the second period of his life) earns receipts from his labour services currently supplied, from the interest on his previous savings, and from the sale of his assets to other agents in the economy. He consumes goods equal in value to these receipts on the assumption that leaving bequests to his offspring gives him no utility, whereas the marginal utility of his own consumption is always positive.

1 A continuous time alternative is given in the appendix. 
The asset the agent can buy and sell is land titles, land being the only factor of production other than labour. Land itself is fixed in supply and the rental services from its use in production earn a positive competitive rate per period of $\mathrm{w}_{\ell}$, measured in units of the numeraire good per unit of land. This return accrues to the owner of the land title. The rate of interest per period is thus this dividend divided by the price of a unit of land. That is to say that:

$$
\mathbf{r} \equiv \mathrm{w}_{\ell} / \mathrm{P}_{\ell}
$$

where $r$ is the rate of interest per period.

How are the land titles distributed among the $N$ agents in the economy? Suppose that at the beginning of time the first two generations ever born randomly divided the land titles among the $\mathrm{N}$ members of society. The old, realizing they couldn't take the land with them, offered to sell their holdings to anyone willing to buy them. The only agents who would be willing to offer a positive price would be the young provided (as is assumed) the rental rate on land is positive. This means that after generation 1 passes away leaving generations 2 and 3 alive, the older group hold all the land titles. By a similar argument, it will always be the case that the old must hold all the land titles whichever pair of generations are alive thereafter. Furthermore, all members of generation 3 begin life with identical tastes and labour endowments. Thus competition ensures that when generation 2 sell their land titles, the subsequent ownèrship will be evenly distributed among members of generation $3 .^{1}$ Thus there is

$1_{\text {These titles can be thought of as being sold "ex dividend", since }}$ to have exchange, agents must arrange contracts at the start of the period with payment being made during the period. Otherwise the young would have no resources if payment was to be made at the start of the perfod and the old would get no utility if payment was made at the very end of the period. 
a completely deterministic distribution of land titles that maintains itself period after period.

Suppose the land-labour ratio, L, for the economy is $\underline{L}$. Then each old agent will hold title to $2 \underline{L}(=(\mathrm{NL}) /(\mathrm{N} / 2))$ units of land. Figure 1 describes the receipts and expenditures of a representative agent of any generation, $t$, throughout his lifetime.

Figure 1

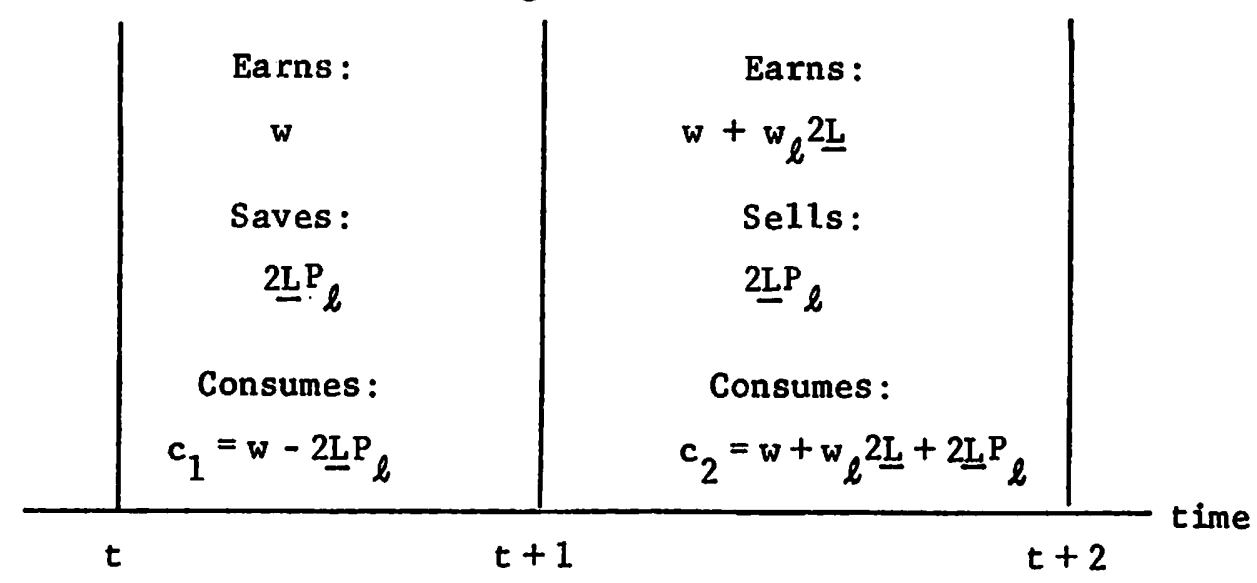

At time $t$ (the start of period $t$ ) he is born, formulates his consumption and saving plans in light of prices of labour, land services, and land titles determined by a Walrasian auction-type mechanism, and enters contracts consistent with these plans. With no loss of generality we assume that only current prices are determined and the agent anticipates that prices determined at time $t+1$ will be the same as in the preceding period. In any case, his consumption and savings plan for the first period of his life will be realized. In the absense of any intervening innovation, prices will be the same next period $^{1}$ so that his consumption plan for the second period will be realized. In this case, since tastes are identical over generations, actual consumption of the old this period will equal planned second period consumption of the young. If there was a new innovation and prices changed, then he cannot do

${ }^{1}$ It is assumed that innovations themselves are not anticipated. If they were anticipated then prices of assets would change prior to the introduction of the innovation, and cause needless complications in making welfare comparisons. 
anything about it anyway, for with positive marginal utility he will consume whatever he can get from selling his labour, the services on his land and his land titles.

III The Welfare Effects of Technical Innovation

Now consider the effects of a technical innovation. Let $y$ denote per capita income and suppose the level of output is a function of the land/1abour ratio, L, and a technological parameter $\xi$. Thus:

$$
y=w+w_{l} L=f(L, \xi)
$$

where $f_{L}>0$ and $f_{\xi} \geq 0$

From competitive behavior:

$$
\begin{aligned}
w_{\ell} & =f_{L} \\
w & =y-f_{L} \quad L
\end{aligned}
$$

Equilibrium at any point in time must therefore imply that :

$$
\begin{aligned}
& c_{1}=w-2 f_{L} L / r=y-w_{\ell} L\left(\frac{1+b}{1-b}\right) \\
& c_{2}=w+2 f_{L} L(1+r) / r=y+w_{\ell} L\left(\frac{(1+b)}{(1-b)}\right)
\end{aligned}
$$

where $c_{1}$ and $c_{2}$ are the per capita consumption levels of the young and old, respectively, ${ }^{1}$ and $b=1 /(1+r)$, which will be called the discount factor. Since $r>0$ it must also be the case the $0<b<1$. Consequently whatever tastes may be, equilibrium--y $=c_{1}+c_{2}$--must mean that consumption of the older generation will be greater than consumption of the young over any given time period. Just what the consumption plan will be depends, of course, on the equilibrium values assumed by $w, w_{\ell}$ and $b$, these values being determined. in the markets for output, labour services, land services and land titles, only three of which are independent. Suppose preferences can be characterized by the additive function: ${ }^{2}$

${ }^{1}$ As pointed out in the preceding paragraph, when there is no price change, planned second period consumption of the young will equal actual current consumption of the old in equilibrium. $c_{2}$ thus describes planned second period consumption of the young as well.

2 The additive form is used for expository convenience. 


$$
U=u\left(c_{1}\right)+\beta u\left(c_{2}\right)
$$

where $\beta=\frac{1}{(1+\rho)}>0$

and $\rho$ is the rate of time preference. It is assumed that

$u\left(c_{i}\right)$ has the normal properties; viz:

$$
\begin{aligned}
& \frac{\partial u\left(c_{i}\right)}{\partial c_{i}}>0 \\
& \frac{\partial^{2} u\left(c_{i}\right)}{\partial c_{i}^{2}}<0
\end{aligned}
$$

The agent wishes to maximize (6) subject to the budget restriction that:

$$
\begin{aligned}
& w(1+b)=c_{1}+b c_{2} \\
& c_{i} \geq 0 \quad i=1,2
\end{aligned}
$$

The marginal condition is:

$$
\frac{\partial u / \partial c_{1}}{\partial u / \partial c_{2}}=\frac{\beta}{b}
$$

Clearly, to meet the condition that $c_{2}>c_{1}$ it must be the case that $b<\beta$ (i.e., $r>p)$. Further, since $c_{2}>c_{1}$, there will be a positive demand for 1 and by the young equal to current period saving divided by $P_{\ell}$. This demand for land titles can be described by:

$$
L^{d}=\left(w-c_{1}(w, b)\right) / P_{\ell}=g\left(w, b, w_{l}\right)
$$

where ${ }^{1} g_{w}>0, g_{b}<0$ and $g_{w_{l}}<0$

let $s=\frac{w}{{ }^{w} \ell}$ be the wage-rental ratio. Then an increase in $s$ causes an increase in the demand for land and given the fixed supply of land, an increase in $b$ (decrease in $r$ ).

Now consider a technical innovation such that total output is unchanged and suppose it is such as to lower the equilibrium wage-rental ratio, $s$, at the given land-labour ratio in the economy. ${ }^{2}$ Given the fixed supply of land,

${ }^{1} A$ sufficient condition for $g_{w}>0$ is that consumption in any period is not an inferior good.

2

From (3) this means $d w / d \xi=-L d w / d \xi$. In land-labour space the innovation implies a rotation of the isoquant about the existing endowment point. 
this means that $b$ must decrease. This, in turn, implies from (9) that first period consumption falls and planned second period consumption rises. Since consumption for the older generation must, in equilibrium, equal total output less the consumption of the young, their actual consumption will just equal what the young plan to do in the next period. It should also be clear that the equilibrium array of $w, w_{b}$, and $b$ immediately after the innovation will continue to be the equilibrium array since tastes, technology and the relative endowments of agents have not changed.

What happens to the young's welfare--and, by extension, all future generations' welfare? It must decrease in the case where s falls. 1 Total lifetime consumption remains the same but, by reallocating consumption to the low marginal utility second period from the high marginal utility fir st period, total utility is reduced. This stems from the fact that the discount factor, $b$, is less than one, an equilibrium condition that follows directly from the assumption that the marginal product of capital is positive.

Now if an innovation that does not change output can reduce welfare of all future generations (and half of the population alive at the time of the innovation), it follows immediately that some technical innovations that increase output may also reduce the welfare of these same generations. This is shown diagrammatically in Figure 2. Panel a. shows the effect of an output increasing technical change on both per capita output and the real wage $\left(w^{i}=y^{i}-f_{L}^{i} \underline{L}\right)$ given the national land labour ratio, L. The young's endowment consists of one unit of wage income in each period and the effect of the innovation is to move the endowment point from $\mathrm{E}^{0}$ to $\mathrm{E}^{1}$ in panel $\mathrm{b} . \overline{O C}^{i}$ describes the offer curve of the agent for consumption now in exchange for

1This can be shown formally: The innovation is such that do $\hat{o}_{1}=-d c_{2}<0$. Now $d U=u^{\prime}\left(c_{1}\right) d c_{1}+\beta u^{\prime}\left(c_{2}\right) d c_{2}$. But $u^{\prime}\left(c_{1}\right)=\frac{\beta}{b} u^{\prime}\left(c_{2}\right)$. Therefore $d U=\beta u^{\prime}\left(c_{2}\right)$ $[(1 / \mathrm{b})-1)] \mathrm{dc} c_{1}<0$. 
FIGURE 2

Pane1 a

Panel b
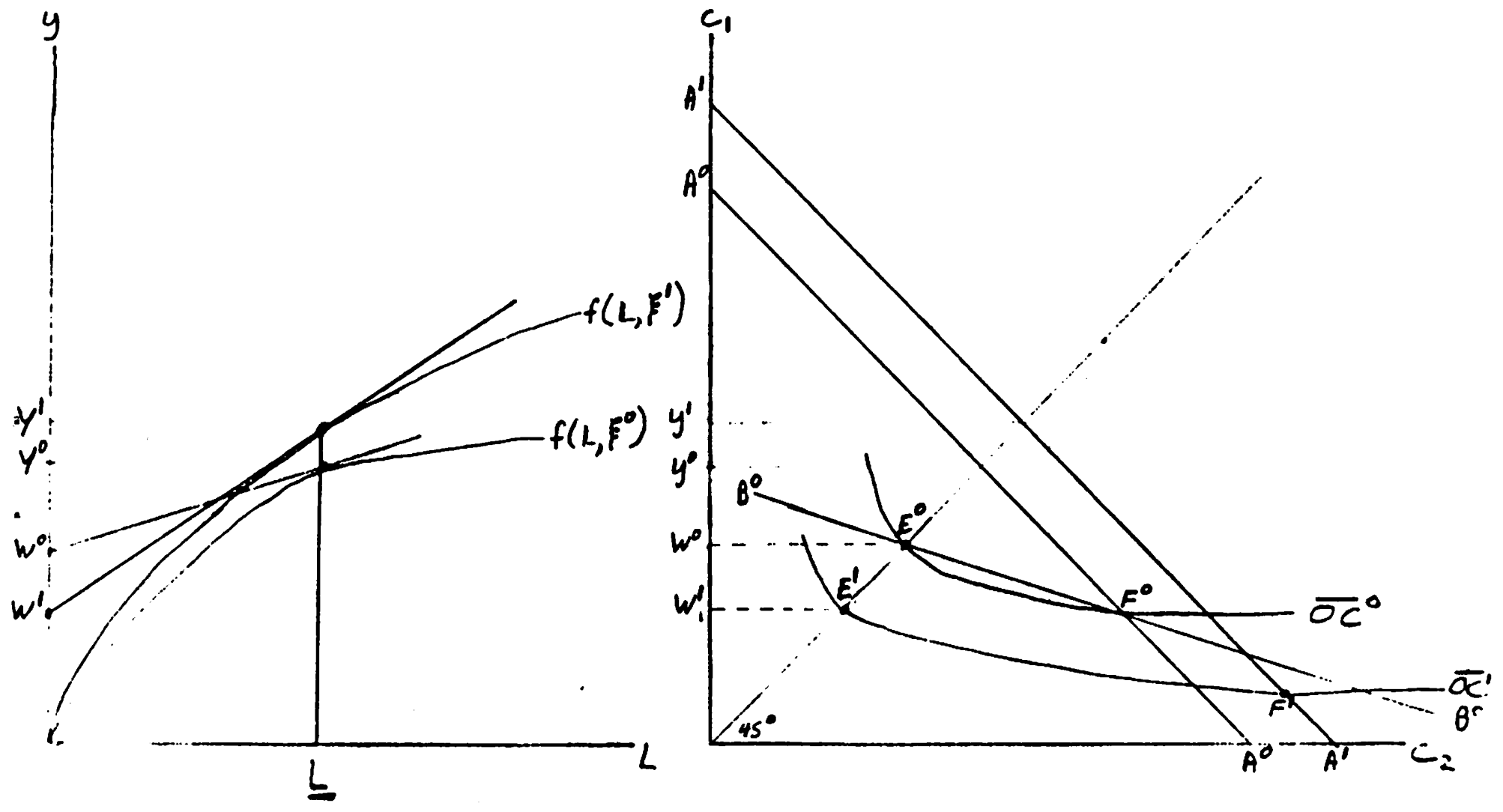
future consumption given the endowment point, $E^{i}$. The slope of the budget line generating the offer curve is $-b$. Equilibrium requires that $c_{1}^{i}+c_{2}^{i}=2 y^{i}$ and these potential equilibrium points are characterized by the lines $\mathrm{A}^{\circ} \mathrm{A}^{\circ}$ and. $A^{1} A^{1}$ passing through $\left(y^{0}, y^{0}\right)$ and $\left(y^{1}, y^{1}\right)$ respectively. The speciffic equilibrium is characterized by the intersection point of the $A^{i} A^{i}$ locus with the $O C^{i}$ locus - points $F^{O}$ and $F^{1}$ in panel $b$. Todetermine whether welfare has increased or decreased from the innovation construct the budget line, ${ }_{B}{ }^{O}{ }^{\circ}$ passing through $E^{\circ} F^{\circ}$. If this curve lies above $F^{1}$ then welfare will fall for future generations since $F^{0}$ is revealed to be preferred to $F^{1}$ even though lifetime consumption is greater at $\mathrm{F}^{1}$.

On the face of it this is an astonishing result. Here is a case where only the current old gain from an unambiguous increase in output and this gain is somehow collected from the yet unborn. Further, after the current old are dead, the economy's total output is higher than it would have been without the innovation; each agent is born with the same tastes and endowments as all the agents born prior to the innovation; and each agent has the same. life-time holdings of assets as an agent born in any other generation; yet all agents born after the innovation are worse off relative to how they would have been if the innovation had not been adopted! How does a "Pareto superior" technical innovation cause everyone who is born after the innovation to have lower levels of welfare than every agent who used the "Pareto inferior" technology despite the fact. that everyone had identical tastes and identical endowments over their lifetimes? It is because what matters is the endowment of agents at a point in time: What they might hold over their lifetimes is just a consequence of the structure of the economy. At the time of the innovation only one generation held land while all other generations held only labour. Consequently a labour saving innovation increases the welfare of the land-holding generation and reduces the welfare of the only labour-holding generations at any given rate 
of interest. The rise in the rate of interest mitigates somewhat the losses due to the worsening of labour's terms of trade but does not alter the fact that this effect applies to endowments at a point in time.

IV The Welfare Effects of International Trade in Consumption Goods

While there is no reason to suppose that technical innovations of the labour saving kind that would cause future generations to be made worse off are common, there is one area in the theoretical literature where the conceptual experiments give rise to exactly the same sort of "innovations" as the one discussed in the previous section. This is in the field of international trade and relates particularly to the literature on the gains from trade. In this section it will be shown that, in an overlapping generations model, the classical experiment of comparing stationary states will, under some circumstances, lead to everyone in at least one country being made worse off with free trade in comnodities than they would have been had the country remained in autarky. The principles involved are the same as in the case of technical change: International trade increases the value of the consumption bundle and the change in relative output prices from their autarkic levels to those prevailing in the rest of the world cause factor prices to change. If the factor price effect reduces the real wage and the change in the value of the consumption bundle is not "too great", then future generations may all lose from the country moving to free trade in consumption goods. In showing that such a result can indeed arise, a specific example is used that should clarify exactly what is occurring. 
It is assumed that there are two goods produced, A and B. Each agent of each generation has the same preferences for these two goods over their lifetime. These preferences are described by

$$
U=\left(\begin{array}{ll}
\alpha & A_{1}+(1-\alpha) \ln B_{1}
\end{array}\right)+\beta\left(\alpha \ln A_{2}+(1-\alpha) \ln B_{2}\right)
$$

where $x_{i}$ is the consumption of the $x^{\text {th }}$ good, $x=A, B$, in the $i^{\text {th }}$ period of the agent's life, $i=1,2$.

Define a composite commodity, $c_{i}$ :

$$
c_{i}=\mathrm{PA}_{i}+\mathrm{B}_{i} \quad i=1,2
$$

where $P$ is the price of $A$ in terms of $B$, the numeraire good.

As is well known, this gives indirect demand functions of the form:

$$
\begin{array}{ll}
A_{i}=\alpha c_{i} / P & i=1,2 \\
B_{i}=(1-\alpha) c_{i} & i=1,2
\end{array}
$$

So that (11) can be rewritten as:

$$
\mathrm{U}=\ln c_{1}+\beta \ln c_{2}-(1+\beta) \alpha \ln \mathrm{P}+\mathrm{K}_{0}
$$

where $K_{0}$ is a constant.

The newborn agent wishes to maximize (13) subject to the restrictions:

$$
\begin{aligned}
w(1+b) & =c_{1}+b c_{2} \\
c_{i} & \geq 0
\end{aligned}
$$

where expected prices in the second period are the same as prevail in the current period. This generates the demand functions for $c_{1}$ and $c_{2}$ of:

$$
\begin{aligned}
& c_{1}=w(1+b) /(1+\beta) \\
& c_{2}=w(1+b) \beta /(1+\beta)
\end{aligned}
$$


Thus the indirect utility function can be written as:

$$
U=(1+\beta) \ln w+(1+\beta) \ln (1+b)-\beta \ln b-(1+\beta) \alpha \ln P+K_{1}
$$

where $K_{1}$ is a constant.

The demand for land by the young is equal in value terms to the planned savings of that generation. Thus, from (14):

$$
L^{d}=\left(1 / P_{\ell}\right)(w-q)=\left(w / P_{\ell}\right)(\beta-b) /(1+\beta)
$$

The supply of land offered by the old is fixed in supply at NL, implying that the available supply to any one of the identical demanders is 2L. From the definitions of $\mathrm{P}_{\ell}$ and $\mathrm{r}$, the land market equilibrium condition can be written as:

$$
\begin{aligned}
\underline{L} & =\left(w / w_{\ell}\right)(r)(\beta-b) / 2(1+\beta) \\
& =s(1-b)(\beta-b) / 2 b(1+\beta)
\end{aligned}
$$

Differentiating (17) and setting the result equal to zero, equilibrium in the land market requires:

$$
\mathrm{db} /\left.\mathrm{ds}\right|_{\mathrm{dL}=0}=\mathrm{b}(1-\mathrm{b})(\beta-\mathrm{b}) / \mathrm{s}\left(\beta-\mathrm{b}^{2}\right) \quad>0
$$

This is to say that an increase in the income, $w$, of demanders relative to the dividend stream, $w_{\ell}$, from land requires the discount factor to rise (the rate of interest to fall) for equilibrium in the land title market.

What determines $s$ ? Basically output prices; a rise (fall) in the relative price of the labour intensive good causing an increase (decrease) in $s$ (cf. StolperSamuelson (1941)). In autarky relative output prices are determined by the interplay of tastes and technology. However, if the country is small, and costless commodity trade is carried out with the rest of the world, then output prices are effectively given by the rest of the world and thus $s$ is given by tastes and technology abroad. To determine explicitly how s changes with a change in relative output prices suppose the production functions are of the simple form that 
the supply of A is a linear function of labour and B a linear function of land. Choosing the appropriate units for A and B, total output of the economy is given by:

$$
\begin{aligned}
& \overline{\mathbf{A}}=\mathrm{N} \\
& \overline{\mathbf{B}}=\mathrm{NL}
\end{aligned}
$$

where $\bar{A}$ and $\bar{B}$ are the total outputs of $A$ and $B$ and $\underline{L}$ is the per capita supply of land in the country.

Then competition implies:

so that:

$$
\begin{aligned}
& w=P \\
& { }^{w}=1
\end{aligned}
$$

Thus an increase in the price of the labour intensive good-comodity A-will cause an equiproportionate change in $s .1$

To consider the effects of free commodity trade on the young differentiate (15) totally with respect to price. This gives

$$
\begin{aligned}
\frac{d U}{d P} & =\frac{(1+\beta)}{P}\left\{\frac{\partial w / \partial P}{(w / P)}-\alpha\right\}-\frac{(\beta-b)}{(1+b) b}(\partial b / \partial s)(d s / d P) \\
& =\frac{1}{P}\left\{(1+\beta)(1-\alpha)-\frac{(\beta-b)^{2}(1-b)}{(1+b)\left(\beta-b^{2}\right)}\right\}
\end{aligned}
$$

Using (17), (21) and the equilibrium condition for the autarkic price level:

$$
P=\frac{\alpha \underline{L}}{1-\alpha}
$$

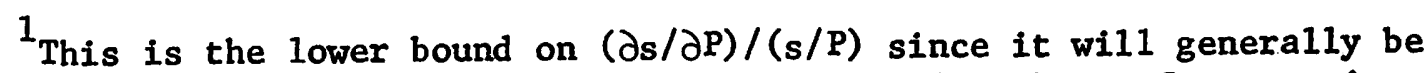
the case that this elasticity will be greater than 1 with one factor price increasing relative to both output prices and the other falling relative to both output prices. In other words, any other production technology would imply a larger decrease in the real wage for any given fall in the relative price of the labour-intensive good. On this, see Stolper-Samuelson (1941). 
it can be shown that $\mathrm{dU} / \mathrm{dP}$ is positive in the region about the autarkic equilibrium. Thus, a fall in the prices of the labour intensive good due to opening the economy to free commodity trade will reduce the welfare of the younger generation alive at the time. This will be associated with a lower value of consumption in the first period of their life and a higher consumption level in their second period relative to what they would have consumed under autarky.

What about the welfare of the older generation alive at the time of the change? They gain since free trade in commodities will increase the total value of consumption and, since the consumption of the young has fallen in their first period it must be the case that the value of consumption of the old has risen relative to what they would have consumed had the country remained in autarky. Over their lifetime, then, they consumed more in their youth under autarky than their offspring will consume under free trade, and will consume more in the second period of their life under free trade than their parents consumed in their old age under autarky.

What about the welfare of future generations? They, as were the young at the time of the change to free trade, are also worse off relative to what they would have been under autarky. Indeed their position is exactly the same as that of the young when the trading regime was altered. This follows from the fact that $P$ will be the same, the age distribution of endowments will be the same, and tastes and technology are unchanged. Consequently the equilibrium $b$ and the time paths of consumption will not be altered. Thus only one generation--the land holders at the time free trade is instituted--gain from free trade and all other generations lose. 
Now consider the classic question of the gains from international trade. The fundamental proposition is that "If a unanimous decision were required in order for trade to be permitted, it would always be possible for those who desired trade to buy off those opposed to trade, with the result that all could be made better off." 2 The example used in this section is not inconsistent with this proposition. It is, in principle, possible for gainers to bribe losers and still obtain a higher level of welfare than under autarky. But how are these sidepayments to be effected? It is physically impossible for the current old to negotiate with members of any generation other than the current young. A11 the other potential losers are not yet born. It would be possible to set up an agency (government) that would carry out the necessary transfers to insure that no one be made worse off but there are two problems that necessarily arise from this. First, it is hard to see why those currently alive would be concerned with the welfare of those who have no voice in the decision of trading regime now. This would be especially true if bribes were necessary only to change the type of trading regime so that once free trade in commodities was instituted it would remain unless the future young could bribe the future old to change it. ${ }^{3}$

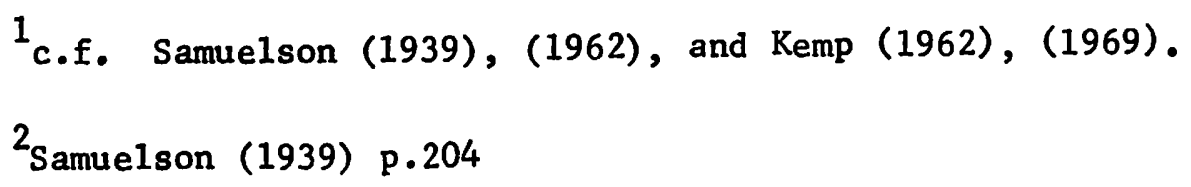

${ }^{3}$ In fact the young could not bribe the old to move back to autarky for the precise reasons given by Samuelson and others in showing the gains from trade: i.e., autarky is not Pareto efficient when commodity trade with the rest of the world is possible. 
Secondly, if such a scheme were initiated it would mean that from an initial innovation relating to market organization what would be required would be an institution that conducted non-market transfers indefinitely into the future. The cost of finding the incidence of a current innovation on those currently alive and providing compensation are large enough in practice. The costs of finding the incidence and providing compensation to those currently alive from every innovation that occurred in the past boggles the mind.

Another interesting aspect of this example is that, in the absence of intergenerational transfers, the standard conceptual experiment of comparing long-run stationary states generates the result that: Everyone who lives his entire life under a regime of free international commodity trade is unambiguously worse off than had he lived his life under an autarky regime. This occurs despite the fact that the time path of every agent's endowments is identical under the two regimes, that perfect competition prevails, and that self sufficiency is not considered a desirable aim. The explanation, of course, for the curious outcome of all agents losing in the long run is that all the gains from free trade are attained by those living during the transition and is associated with the once and for all change in factor prices at the instant that the free trade regime is initiated.

V Free Trade in Land Titles

So far it has been argued that free trade in consumption goods can, in the long run, make everyone worse off. In this section the effects of free trade in land titles and consumption goods are considered. The example of the previous section will be used to illustrate the points to be made. 
There are two issues to be considered. First, how will the welfare of future generations be affected by trade in titles and commodities (denoted simply as free trade) relative to (a) trade in commodities alone (portfolio autarky) and (b) complete autarky $?^{1}$ second, what are the effects of commodity tariffs on welfare and asset holdings? Conceptually, free trade differs from portfolio autarky in that, for the small economy, both $\mathrm{P}$ and $\mathrm{b}$ are set in the rest of the world rather than just $P$ (with $b$ adjusting according to domestic demand and supply conditions).

In Figure 3, the set of possible equilibrium points for a country having free trade are those with $P>0$ and $0<b<1$. To compare free trade with complete autarky suppose the point $\left(\mathrm{P}_{0}, \mathrm{~b}_{0}\right)$ describes the no-trade equilibrium. Then construct $\mathrm{U}^{*} \mathrm{U}^{*}$, the locus of points in $(\mathrm{P}, \mathrm{b})$ space that generate the same level of welfare for future generations as could be achieved under complete autarky. It will pass through $\left(P_{0}, b_{0}\right)$ and the slope of this "iso-welfare" curve is obtained by differentiating (15) totally with respect to $P$ and $b$ :

$$
\begin{aligned}
\mathrm{db} /\left.\mathrm{dP}\right|_{\mathrm{dU}=0} & =\frac{\mathrm{b}(1+\mathrm{b})(1+\beta)\left(\frac{\partial w / \partial \mathrm{P}}{\mathrm{w} / \mathrm{P}}-\alpha\right)}{\mathrm{P}(\beta-\mathrm{b})} \\
& =\frac{\mathrm{b}(1+\mathrm{b})(1+\beta)(1-\alpha)}{\mathrm{P}(\beta-\mathrm{b})}
\end{aligned}
$$

which is positive or negative as $\beta$ is greater or less than $b .^{2}$

Free trade arrays west of $U^{*} U^{*}$ generate welfare levels for future

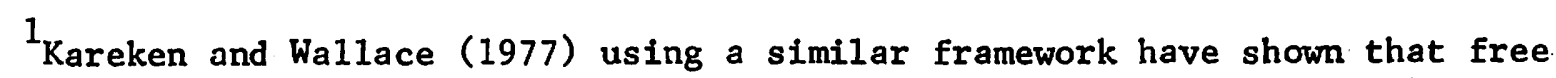
trade in titles and commodities is Pareto optimal and that portfolio autarky is not, given that transfers can be costlessly arranged such that any potential losers can be provided compensation. In this section the assumption is retained that such transfers do not take place and stress is again put on situations where all future generations of at least one country lose from the Pareto optimal solution.

${ }^{2}$ For $1>b>\beta$, agents are assumed to be able to borrow in their youth on the promise to pay the lender from their second period wages. If there are constraints on borrowing on this type of collateral then $U * U *$ would be described by a vertical line passing through point $B$ in Figure II over the range $\beta \leq b<1$. 
FIGURE 3

s

$a$

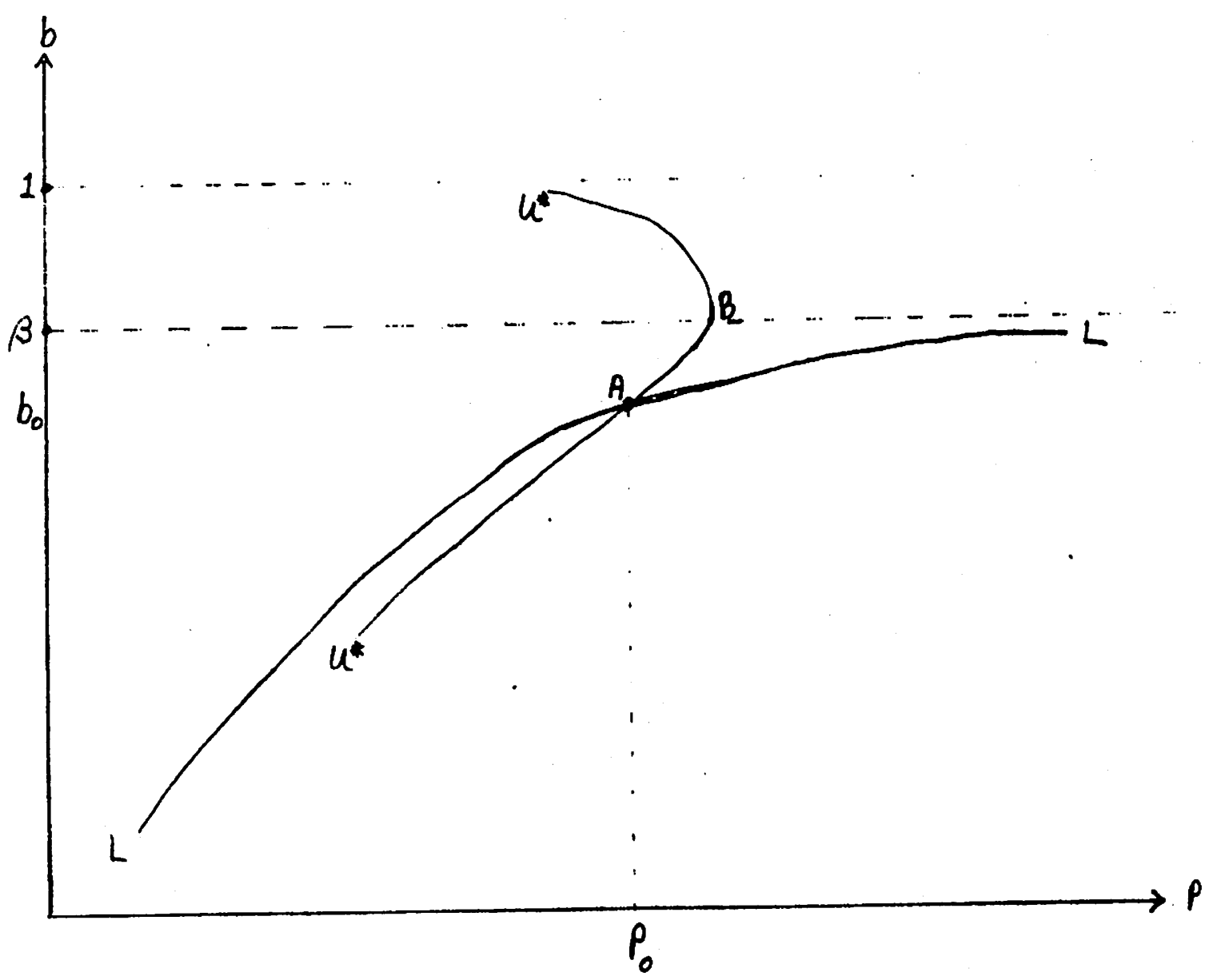


generations lower than would prevail under autarky. East of U*U* welfare will be higher with free trade. That free trade can either improve or worsen the welfare of all future generations in an economy should not be surprising given the discussion of the previous section. A more interesting question would be whether future generations in an economy that is a net debtor ${ }^{1}$ can be made better off with free trade. ${ }^{2}$ The answer is that they could, but need not be. To see this consider the curve LL curve in Figure 3 that describes the locus of possible equilibria with portfolio autarky and thus describes ( $P, b)$ combinations under free trade where the country is neither a debtor or creditor in land titles. This "portfolio autarky" locus is derived by solving (17) for b given any world terms of trade (and hence s). Its slope is given by substituting from (21) into (18):

$$
\left.\frac{d b}{d P}\right|_{d L=0}=\frac{b(1-b)(\beta-b)}{P\left(\beta-b^{2}\right)}>0
$$

Northwest of IL the country is a debtor and below LL it is a creditor. As was indicated in the previous section, future generations lose over at least some range of LL to the left of the autarkic equilibrium which implies that LL intersects $U * U *$ from above. Since the two curves intersect it must be the case that over some range $\left(P>P_{0}\right)$ the country could be a debtor and future generations must be better off.

Are future generations better off with portfolio autarky or free trade? If the country would be a debtor under free trade and the world $b$ is no more than the domestic social discount factor $\beta_{1}^{3}$ then future generations will be

${ }^{1}$ An economy is a debtor (creditor) if the number of land titles held by agents in that economy is less (more) than the number of titles associated with the land in the economy. Individuals within the econony will be debtors (creditors) if $\beta$ is less (more) than $b$.

${ }^{2}$ Gale (1971), (1974) and Green (1972) have also looked at this issue using a somewhat different model that includes only one consumption good.

${ }^{3}$ If agents cannot borrow on their future labour income then it is not necessary to restrict this statement to $\beta \geq b$. 
unambiguously better off with portfolio autarky than they would be living under a free trade regime. This follows from the fact that $\partial U / \partial b<0$ for $\beta>b$. Since, for any given $\mathrm{P}$, a debtor position is characterized by a b greater than the $b$ that would prevail under portfolio autarky, it must be the case that portfolio autarky is preferable to free trade in the eyes of the younger and future generations. There is a quite simple interpretation of this result: If, at any given $P$, the world's demand price for the home country's land titles, $\frac{w}{1-b}$, is greater than would be the demand price of the young and future generations within the home country in the absence of foreign demanders, the home country's youth will demand fewer land titles under free trade than under portfolio autarky. Given factor prices, therefore, the higher equilibrium price of land under free trade gives the young fewer claims on real resources and thus reduces their welfare relative to portfolio autarky. The (radica1?) young would therefore prefer a situation where "foreigners" did not hold any of the home country's land titles. Of course, given factor prices, the older generation would prefer the highest demand price possible for the land titles which they intend to sell and hence would prefer free trade to portfolio autarky if, under free trade, the country would become a net debtor. 1

Suppose now that a snall open economy operating under a regime of free trade of land titles and commodities institutes a tariff on the imported consumption good. What are the welfare effects on future generations of this change and how does it alter land holding patterns? Ignoring how the tariff revenue is distributed for the moment it is clear that, to the extent that the domestic price of the labour intensive commodity rises, future generations will be made better off. Further, at the given world $b$, the increase in the wage rate increases the young's wealth, $w(1+b)$, and thus increases their demand for land titles. Consequently, a tariff that improves the welfare of the young at any given rate of interest will reduce the net indebtedness (increase

If the country would be a net creditor under a free trade regime then the young and olds preferred trading regime would be reversed. 
the net credit position) of the country to the rest of the world. Furthermore, if agents throughout the world have identical tastes, if conditions for factor price equalization prevail and if countries differ only in their land-labour ratios, then it can be shown that the country for whom a tariff would increase the price of the labour intensive good is a net debtor in land titles. ${ }^{1}$ Under this standard reason for trade, then, the imposition of a tariff tends to move the world toward portfolio autarky. ${ }^{2}$ Now suppose the tariff revenue from the import of the labour intensive good is distributed equally among young and old at the time of collection. This, by adding further to the younger generation's wealth at given $b$ and first period income, further increases the young's (and future generations') welfare and land holdings. 3

${ }^{1}$ A sketch of the proof is as follows: Under free trade with factor price equalization all agents in the world would have the same consumption plans and land holdings. Let $L^{*}$ denote the world land-labour ratio. Then the country importing the labour intensive gnod has a land-labour ratio $\underline{L}, \underline{L}>L^{*}$ Suppose this country went to complete autarky and that a sufficient amount of land was taken out of production to cause the effective land-labour ratio equal $L^{*}$. Then agents would face the same $(P, b)$ as under free trade and the demand for land would be the same as under free trade. Since the land is not taken out of production under free trade it must be the case that the rest of the world holds title to some of the country's land. Incidentally, the equilibrium expansion path of $b$ and $P$ due to changes in $L$ may be negatively as well as positively sloped in ( $P, b)$ space. In fact, in the example of the last section it is horizontal.

${ }^{2}$ It is not quite proper to characterize this tariff situation as reducing capital flows since after one period net capital flows are zero corresponding to the stationary equilibrium condition.

${ }^{3}$ Exactly how the revenue is distributed between young and old is crucial to the welfare of future and current generations. The more that goes to the younger generation, the greater will be the welfare of that and future generations and the lower will be the net indebtedness of the country. Indeed, if the government expropriated all land and all labour income from all agents, (and required agents to work as much as they did before the "revolution") and provided the young with real claims on goods equal in value to $2 \mathrm{y}$ to be spent over both periods of life then future generations would have the maximum welfare possible. Such a characterization would correspond to Samuelson's (1958) exact consumption loan model with the optimum rate of interest equal to zero (the rate of population growth). However, the generation whose land is expropriated would likely raise some objections to such a transfer scheme and it would be impossible to bribe that generation sufficiently to voluntarily bring the transfer about. 
What would happen to the welfare of future generations if a similar. tariff and transfer mechanism were instituted when the country was initially in a portfolio autarky? Here the results are less clear cut because the tariff can be thought of as a negative innovation, causing aggregate income to fall while factor prices change in favor of the young. Which of these aspects dominate depends upon the nature of tastes and technology. Furthermore, it cannot even be determined a priori whether or not future generations are better off with a tariff and a free trade regime or the same tariff and portfolio autarky since this will depend on the world b relative to the b that would prevail at the effective $P$ in the home country under portfolio autarky. If the world discount factor is less than the portfolio autarky $b$, then the country would become a net creditor in land titles and free trade (with tariffs) would make the young and future generations better off than with portfolio autarky. 
In this paper the welfare effects of a technical or trading regime innovation were examined in the context of an overlapping generations model. The basic point that is made is that in the absence of intergenerational transfers an innovation that in principle, could make everyone better off may make virtually everyone worse off despite the fact that the innovation does not change the lifetime profile of any agent's endowments.

It is, of course, well known that if endowments differ, some agents may lose in the presence of an income increasing innovation. What has not been recognized is just how widespread such losses may actually be. For example, the comparative static experiment of examining the gains from international trade may show that everyone living in a country that permits free international trade in consumption goods is worse off than his counterpart who lived under a complete autarky and held the same factors of production. If pressed I suspect that most economists would have said that, in the long run, free trade would make at least some agents in a country better off. Furthermore, the problems of actually providing compensation are shown to be enourmously compounded when viewed in an intertemporal context. To be consistent, not only must those currently alive be compensated for welfare losses arising from current innovations, but compensation for all previous innovations would also have to be arranged. Too, any current innovations will entail a trail of transfers extending indefinitely into the future. What this suggests is that economists probably should become even more cautious in going from welfare analysis to economic policy questions, since the distribution question simply cannot be disentangled from the question of efficiency and involves agents not yet born. 1

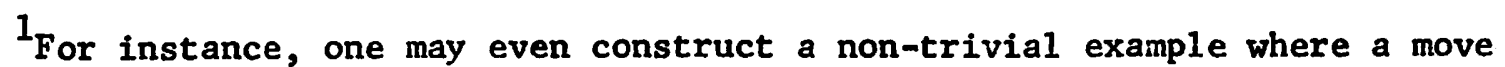
from unemployment to full employment could make future generations, as well as all workers, worse off. Such an example would recognize that unemployment is a life cycle phenomenon. 
A major issue raised by the analysis concerns whether or not agents in an economy would introduce and/or maintain an institutional or technical innovation which would cause virtually everyone to be worse off. The answer to this question revolves around just who are the relevant groups that make the decisions. In the technological innovation case, for instance, if owners of land are also those who control the firms, then the innovation would likely be undertaken since it increases the real return on, and real value of, land titles. Further, when future generations become land holders it would never be in their interest to return to the old technology and suffer the fall in return and in the real price of land titles. In the case of international trade the relevant decision makers are the two generations alive at the time the possibility for trade arises. Here half the population gains and half the population loses from trade. If (as, empirically, is the case) compensation is (almost) never provided and the choice of trading regime is made by democratic vote of all workers alive, then the move to trade may or may not be chosen, the voting population being evenly divided between potential gainers and losers. With more than two generations, the interests of future generations are less likely to be represented since only the youngest generation's interests would coincide with those yet to be born. Consequently there are circumstances where the decision would favor an outcome inimical to the interest of future generations. 1

Suppose, at some time, a majority chose some form of international trade over no trade. Could it be possible that some time in the future the generations alive would choose to return to autarky or some form of partial protection even though tastes of those individuals are identical to those of the generations

\footnotetext{
$1_{\text {This }}$ issue is examined in more detail in the appendix.
} 
that chose trade? The answer is that it is, especially if the country is a debtor nation under trade. ${ }^{1}$ The reason for this is that the age distribution of the ratio of human to total wealth is a function of relative output prices and interest rates and thus is dependent on the type of trading regime. Once it is admitted that the relative holdings of endowments will differ, then it follows that voting patterns will differ, and it is quite possible that an initial decision on trading regime will be overturned sometime in the future. ${ }^{2,3}$ The overall conclusion would therefore appear to be that, if individuals are transitory on this eartho then so too may be the gains from innovations and institutional forms.

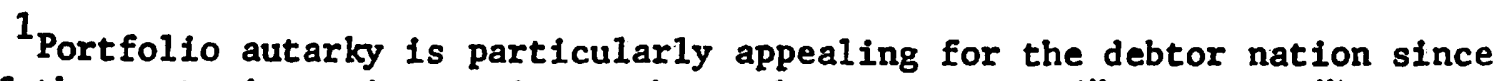
some of the costs in moving to it are borne by non-voters ("foreigners") rather than: being all borze by the older agents.

This observation is not inconsistent with the observations that tariff levels appear to exhibit historical fluctuations or that the intensity of economic nationalism (for portfolio autarky) is currently on the rise.

3 The appendix provides an example of this trading regime "instability". 


\section{Appendix}

In this appendix the results are generalized to encompass multiple periods rather than just the two-period life span used in the text. In particular the ugent is assumed to live for a finite interval, $T$, and makes consumption and savings decisions continuously. For convenience the continuous time equivalent of the example of Sections III and IV is used. Additional implications regarding voting behavior on choice of trading regime are also discussed.

The representative agent of age $\tau, 0 \leq T \leq T$, is assumed to have preferences of the form:

$$
\begin{aligned}
U(\tau) & =\int_{T}^{T}(\alpha \ln A(t)+(1-\alpha) \ln B(t)) e^{-\rho t} d t \\
& =\int_{T}^{T}(\ln C(t)-\alpha \ln P) e^{-\rho t} d t
\end{aligned}
$$

where $C(t)=P A(t)+B(t)$.

$A(t), B(t)$ and $C(t)$ are the consumption at time $t$ of the labour intensive good, the land intensive good and aggregate consumption, respectively. $P$ is the price of $A$ in terms of $B$ and is expected to remain constant over the interval $T$ to $T$.

The budget restriction is:

$$
\dot{L}(t)=\left(1 / P_{\ell}\right)(y(t)-c(t))
$$

where

$$
\begin{aligned}
& y(t)=w+r P_{\ell} \cdot L(t)=\text { aggregate income at time } t \\
& \mathbf{w}=\text { the wage rate } \\
& r=\text { the rate of interest } \\
& \mathrm{P}_{\ell} \equiv \mathrm{w}_{\ell} / \mathrm{r}=\text { the price of a title to one unit of land } \\
& w_{l}=\text { the rental rate for a unit of land } \\
& L(t)=\text { holdings of land at age } t \\
& \text { and } \quad \dot{X}(t)=\text { the time derivative of } x \text { at time } t \text {. }
\end{aligned}
$$


The assumption of no bequests imposes the initial and terminal conditions of:

$$
L(0)=L(T)=0
$$

The non-negativity restriction on consumption is:

$$
c_{i}(t) \geq 0 \quad i=1,2 . \quad t \in(0, T)
$$

As is well known (cf. Yaari (1964), or Cass and Yaari (1967)), the optimal aggregate consumption plan formulated at age $\tau$ is characterized by:

$$
C(t ; \tau)=\frac{V(\tau) e^{a(t-\tau)}}{\phi(\rho ; \gamma)}, T \geq t \geq \tau
$$

where

$$
\begin{aligned}
a & =r-\rho \\
\gamma & =T-T \\
V(T) & =W \phi(r ; \gamma)+P_{\ell} L(T)=\text { human plus non-human wealth at age } \tau,
\end{aligned}
$$

and

$$
\phi(x, y)=\left(1-e^{-x y}\right) / x \text {, a capitalization factor. } .^{1}
$$

Substituting (A.5) into (A1) the expected level of welfare for an agent aged $\tau$ facing given prices of goods, land titles and factors is:

$$
\mathrm{U}(\tau)=\mathrm{K}_{0}(\tau)+\phi(\rho, \gamma)(\ln \mathrm{V}(\tau)-\alpha \ln \mathrm{P})-\mathbf{r} \phi^{\prime}(\rho ; \gamma)
$$

where $K_{0}(T)^{\prime}$ is a constant independent of prices and the interest rate and $\phi^{*}(x ; y)=\partial \phi / \partial x<0$

Using the same technological assumptions used in Section IV so that $w_{l}=1$ and $w=P$ the expected welfare of an agent just beginning his economic life is :

$$
\begin{aligned}
\mathrm{U}(0) & =\mathrm{K}_{0}(0)+\phi(\rho ; \mathrm{T})(\ln \mathrm{P} \phi(\mathrm{r} ; \mathrm{T})-\alpha \ln \mathrm{P})-\mathrm{r} \phi^{\prime}(\rho ; \mathrm{T}) \\
& =\mathrm{K}_{0}(0)+\phi(\rho ; \mathrm{T})(\ln \phi(\mathrm{r} ; \mathrm{T})+(1-\alpha) \ln \mathrm{P})-\mathrm{r} \phi^{\prime}(\rho ; \mathrm{T})
\end{aligned}
$$

1 1 The discrete time equivalent of $\phi(x, y)$ is $\sum_{t=0}^{y}\left(1 /(1+x)^{t}\right)$. 
The stationary state is characterized by constant prices over time which, in this model, translates into the condition that all agents alive plan to have identical life cycle paths of consumption and land title holdings. To describe the stationary state equilibrium for autarky thus involves showing that the average level of consumption of B and A over any agent's IIfe equals the per capita supply of $A$ and $B$ and that his average holdings of land over his lifetime, $\bar{L}$, is equal to the per capita supply of land, $L$. The per capita supplies of $A$ and $B$ under the technology assumed in Section IV is $\bar{A}=1$ and $\bar{B}=\underline{L}$. Thus the autarkic equilibrium price is:

$$
\hat{\mathrm{P}}=\frac{\alpha}{1-\alpha} \underline{L}
$$

The planned holdings of land at any age $\tau, 0<\tau \leq T$, as planned at age zero when an agent faces a given $P$ and $r$ is:

$$
L(\tau)=\operatorname{Pr} e^{I T}\left[\frac{\phi(r ; \tau)}{\phi(r ; T)}-\frac{\phi(\rho ; \tau)}{\phi(\rho ; T)}\right]
$$

Integrating $L(T) / T$ over an agent's entire life gives his average holdIngs of land titles, $\bar{L}$, for given $P$ and $r$ of:

$$
\overline{\mathrm{L}}=\frac{\mathrm{P}}{\mathrm{T}}\left\{\frac{\phi(\mathrm{r} ; \mathrm{T}) \phi(\mathrm{a} ; \mathrm{T}) \mathrm{e}^{a \mathrm{~T}}}{\phi(\mathrm{o} ; \mathrm{T})}-\mathrm{T}\right\}
$$

Using (A 10), (A 8), and $\bar{L}=\underline{L}$, the autarkic equilibrium rate of interest, $\hat{P}$, is characterized by:

$\phi(\hat{\mathbf{r}} ; \mathrm{T}) \phi(\hat{\mathbf{a}} ; \mathrm{T}) \mathrm{e}^{\hat{\mathrm{a} T}}=\mathrm{T} \phi(\rho, \mathrm{T}) / \alpha$

To show that welfare levels of agents living under the portfolio autarky stationary state may be lower than would have been the case if agents lived in the autarkic stationary state, it is sufficient to argue that an autarkic isowelfare locus, characterized by $\mathrm{dr} /\left.\mathrm{dP}\right|_{\mathrm{dU}(0)=0}$ about $(\hat{P}, \hat{\mathrm{r}})$ in $(P, r)$ space intersects the locus of equilibrium states that would prevail with portfolio autarky 
as $\mathrm{P}$ is altered. The portfolio autarky locus is characterized by $\mathrm{dr} / \mathrm{dP} / \mathrm{d} \overline{\mathrm{L}}=0^{\circ}$ Consider $d r /\left.d P\right|_{d U(0)=0}$ first. Differentiating (A7). totally with respect: to $r$ and $P$ gives:

$$
\mathrm{dU}(0)=[\phi(\rho ; \mathrm{T})(1-\alpha) / \mathrm{P}] \mathrm{dP}+\phi(\rho ; \mathrm{T})\left[\frac{\phi^{\prime}(\mathrm{r}, \mathrm{T})}{\phi(\mathrm{r}, \mathrm{T})}-\frac{\phi^{\prime}(\rho . \mathrm{T})}{\phi(\rho, \mathrm{T})}\right] \mathrm{dr}
$$

where $\phi^{\prime}(x, y)<0$, and $\frac{\phi^{\prime}(r, T)}{\phi(r, T)}>\frac{\phi^{\prime}(\rho, T)}{\phi(\rho, T)}$ for $r>\rho$. Setting dU(0)=0 about $(\hat{P}, \hat{x})$ gives:

$$
\mathrm{dr} /\left.\mathrm{dP}\right|_{\mathrm{dU}(0)=0}=-\frac{1-\alpha}{\mathrm{P}}\left\{\frac{1}{\frac{\phi^{2}(\mathrm{r} ; \mathrm{T})}{\phi(r ; T)}-\frac{\phi^{\prime}(\rho, T)}{\phi(\rho, T)}}\right)<0
$$

for $r>\rho$.

The portfolio autarky locus is found by differentiating (A 10) with respect to $r$ and $P$ and setting $d \bar{L}=0$ :

$$
d \bar{L}=\frac{\bar{L}}{P} d P+(\bar{L}+P)\left[\frac{\phi^{\prime}(r ; T)}{\phi(r ; T)}+\frac{\phi^{\prime}(a ; T)}{\phi(a: T)}+T\right] d x=0
$$

Solving for $\mathrm{dr} /\left.\mathrm{dP}\right|_{\mathrm{d} \overline{\mathrm{L}}=0}$ :

$$
\left.\frac{d r}{d P}\right|_{d \bar{L}=0}=-\frac{\bar{L}}{P(\bar{L}+P)}\left\{\frac{1}{\frac{\phi^{\prime}(r ; T)}{\phi(r ; T)}+\frac{\phi^{\prime}(a ; T)}{\phi(a ; T)}+T}\right\}
$$

Setting $\overline{\mathrm{L}}=\underline{\mathrm{L}}$ and using (A8) this can be rewritten as :

$$
\left.\frac{\mathrm{dr}}{\mathrm{dP}}\right|_{\mathrm{d} \overline{\mathrm{L}}=0}=-\frac{1-\alpha}{\hat{\mathrm{P}}}\left(\frac{1}{\frac{\phi^{\prime}(\hat{\hat{r}} ; \mathrm{T})}{\phi(\hat{\mathrm{r}} ; \mathrm{T})}+\frac{\phi^{\prime}(\hat{\mathrm{a}} ; \mathrm{T})}{\phi(\hat{\mathrm{a}} ; \mathrm{T})}+\mathrm{T}}\right)
$$

which gives the slope of the portfolio autarky locus at the complete autarky equilibrium $(\hat{P}, \hat{r})$.

To determine if the iso-welfare and portfolio autarky loci intersect at $(\hat{P}, \hat{r})$ subtract the latter from the former: 


$$
\Psi(U(0) ; \mathrm{L})=\mathrm{dr} /\left.\mathrm{dP}\right|_{\mathrm{dU}(0)=0}-\mathrm{dr} /\left.\mathrm{dP}\right|_{\mathrm{d} \overline{\mathrm{L}}=0}
$$

$$
=-\frac{(1-\alpha)}{\hat{\mathrm{P}}\left(\frac{\phi^{\prime}(\hat{r} ; T)}{\phi(\hat{r} ; T)}-\frac{\phi^{\prime}(\rho ; T)}{\phi(\rho ; T)}\right)}\left[\frac{\frac{\phi^{\prime}(\hat{a} ; T)}{\phi^{\prime}(\hat{a} ; T)}+\frac{\phi^{\prime}(\rho ; T)}{\phi(\rho ; T)}+T}{\frac{\phi^{\prime}(\hat{a} ; T)}{\phi(\hat{a} ; T)}+\frac{\phi^{\prime}(\hat{r} ; T)}{\phi(\hat{r} ; T)}+T}\right]
$$

To sign (A17) use (A11), the condition for determining $\hat{r}$, and find $d \hat{r} / d \rho$ :

$$
\frac{d \hat{r}}{d \rho}=\frac{\frac{\phi^{\prime}(a ; T)}{\phi(a ; T)}+\frac{\phi^{\prime}(\rho ; T)}{\phi(\rho ; T)}+T}{\frac{\phi^{\prime}(a ; T)}{\phi(a ; T)}+\frac{\phi^{\prime}(r ; T)}{\phi(r ; T)}+T}
$$

which is the bracketed term in (A17). It seems reasonable to suppose that a change in the rate of time preference will generally affect the equilibrium rate of interest and, in particular, an increase in the relative preference for current consumption will increase the equilibrium rate of interest. Consequently, $\Psi(U(0) ; \underline{L})$ will be negative which means that the isowelfare and portfolio autarky curves intersect with the former having the steeper (negative) slope. Thus a small decrease in $P$, the relative price of the labour intensive good, would make future generations worse off under portfollo autarky than they would have been had the country remained in complete autarky. It also follows immediately that under some arrays of $(P, r)$ they would also be worse off under free trade relative to complete autarky even if the country is a net creditor with free trade.

A second issue that the continuous time model can shed light on is, if the choice of trading regime is made by majority vote, under what conditions would an initial choice of free trade at one point in time lead to a decision for restrictions on trade at some point in the future. This issue cannot be handled properly in the two generation model since the voting mechanism would 
generate either a tie or a unanimous vote. The modelling of choice of trading regime by majority vote is possible in the continuous time framework used here since there are a continuum of generations alive at any point in time. Consequently the analysis can be handled with standard calculus. For expository convenience it is assumed that the economy is sufficiently small so that the world $P$ and $r$ are unaffected by the home country's trading regime.

The crucial element in choice of regime is the individual's mix of human and non-human capital at the time the decision on trading regime is made. Let $h(\tau)$ describe the ratio of human to total capital in the portfolio of an agent of age $\tau$. That is:

$$
h(T)=\frac{w\left(1-e^{-r \gamma}\right)}{r} /\left(\frac{w\left(1-e^{-r \gamma}\right)}{r}+\frac{w e^{L(T)}}{r}\right)
$$

It can be shown for $r>\rho$ and given $r$ and $P$ that:

$$
\mathrm{dh}(\tau) / \mathrm{d} \tau=h(\tau)\left[\frac{1}{\phi(\rho ; \gamma)}-\frac{1}{\phi(r ; \gamma)}\right]<0
$$

for preference: described by (A1). Thus $h(\tau)$ is a monitonically decreasing function of $\tau$ that has its maximum value at $\tau=0$ where $h(0)=1$. Furthermore, given constant $r$ and $P$ during the interval up to age $\tau$, a change in $P$ at age $\tau$ will affect $h(\tau)$ by :

$$
\mathrm{dh}(\tau) / \mathrm{dP}=\frac{\phi(r ; \gamma)}{\mathrm{V}(\tau)}(1-\mathrm{h}(\tau))>0
$$

for $T>0$.

When an economy is opened to trade, the subsequent change in $P$ and $r$ will affect the total remaining welfare of an agent of age $\tau$ at the time of the change. These two effects can be described by differentiating (A6) with respect to $P$ and $r$ :

$$
\begin{aligned}
& \partial \mathrm{U}(\tau) / \partial \mathrm{P}=\frac{\phi(\rho ; \gamma)}{\mathrm{P}}(\mathrm{h}(\tau)-\alpha) \\
& \partial \mathrm{U}(\tau) / \partial \mathbf{r}=\phi(\rho ; \gamma)\left[\frac{\partial \mathrm{V}(\tau) / \partial \mathbf{r}}{\mathrm{V}(\tau)}-\frac{\phi^{\prime}(\rho ; \gamma)}{\phi(\rho ; \gamma)}\right]
\end{aligned}
$$


Generally speaking, the young would have increased welfare from (and would vote for) free trade if such a move increased both $P$ and $r$ while the old would choose free trade if $P$ and $r$ fell. The agent, aged $T_{P}$, who would be indifferent to a small change in $P$ (the marginal voter with respect to terms of trade effects) would be described as having $h\left(\tau_{P}\right)=\alpha$; that is, he would be in a personal state of autarky having a personal ratio of human to total wealth equal to the ratio of human to total inputs in his consumption bundle. The marginal voter, aged $\tau_{r}$, with respect to interest rate changes could also be described as in a form of personal autarky. For him, the percentage change in his wealth from a change in $r$ would equal the percentage change in the present value of his consumption evaluated at his personal rate of time preference.

For expository convenience suppose that the world rate of interest equalled the autarkic rate of interest in the home country. This would occur, for instance, . if the tastes and technology of the world were the same as those described for the home country and nations differed only in respect to their land-labour ratios. A movement to free trade then only depends on whether a majority gain from the change in the terms of trade. Suppose that $\tau_{P}<T / 2$. Then a sma11 decrease in $P$ will make more than half of the population better off, and the economy would choose free trade for any fall in $\mathrm{P} .^{1}$ What about a rise in $P$ ? Any increase would be preferred by the youngest $T_{P} / T$ share of the population. Further, the greater the rise, the greater the number of individuals who would prefer free trade to autarky. This is because as $P$ rises, $h(\tau)$ increases relative to $\alpha$, the share of labour embodied in the agent's consumption bundle. Consequently as $\mathrm{P}$ rises, more and more agents find it in their self interest to choose trade at this higher price relative to the initial price.

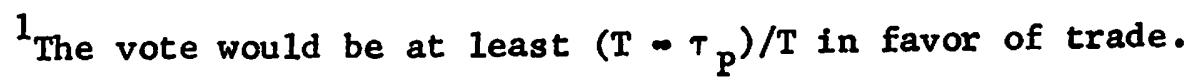


Flgure 4 describes the galners and losers for any given change in P. The shaded area shows which ages lose for any change in price. An economy will choose to change trading regime if $\mathbf{r}$ is constant and the representative voter, aged $T / 2$, gains from the change. As drawn any decrease in $P$ or any

Figure 4

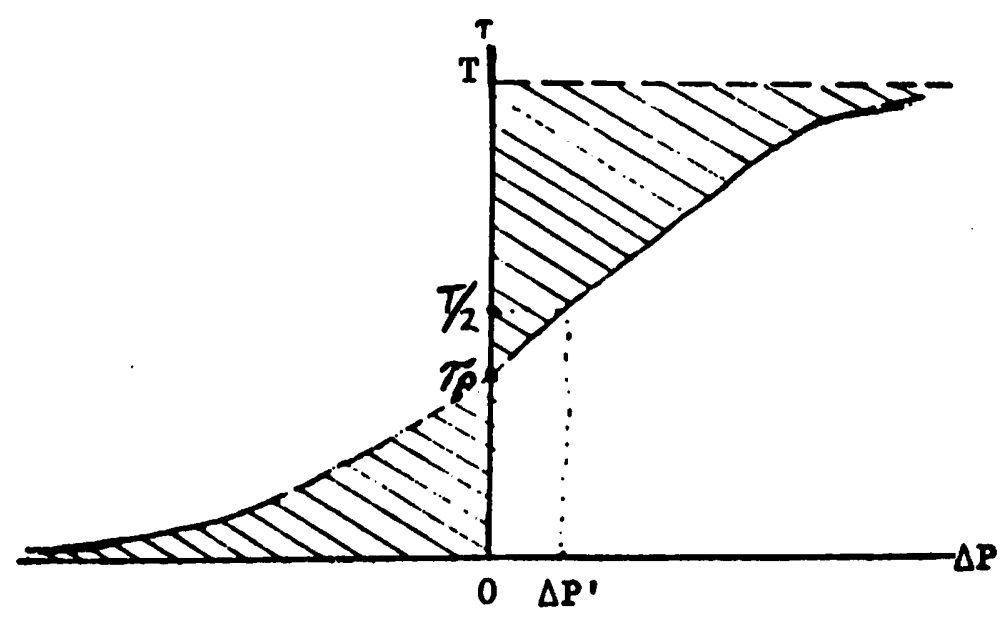

Increase greater than $\Delta P^{\prime}$ will make a majority better off from the change. Suppose that the home country had a higher land-laboux ratio than the rest of the world and thus free trade entalled a decrease in P. A majority would then support the move to free trade and further, would support such a move to any partial movement in that direction because the greater the fall in $P$ the more agents who would gain and the greater would be the gains to any Individual who did gain. Now let the economy grind out the new, free trade stationary state. This will be characterized by the country being a debtor and welfare levels of agents being lower than they would have been in autarky. However, from (A20), h(T) will be the same in free trade as it was in autarky since, by assumption, $r$ is unchanged. Hence, if a new vote was taken on whether to remain with free trade or to impose 
tariffs, a majority of the population would choose tariffs provided the change in price was sufficiently great (for example, greater than $\Delta \mathrm{P}^{\prime}$ in Figure 4). Why is this? It is because in the future agents will have adjusted their portfolios to the new $P$ which under the assumptions about tastes and technology will mean that the portfolio composition will be unchanged although the value of wealth of any agent, aged $\tau$, will be less than it wculd have been under autarky. By imposing a tariff not only will the wage rise, thus increasing wealth, but the rental rate on land will fall thus causing $P_{\ell}$ to fall. Because the country is a net debtor, this means some of the costs will be borne by non-residents. True, the old may also suffer on their land holdings, but the middle-aged will gain on balance, with the wage increase more than offsetting the fall in the value of the land they own. In the case of the middle-aged initially choosing free trade, the greater absolute amount of land holdings meant that they gained more from the rise in the price of land than their offspring would lose from the fall in the price of land.

The fact that it is possible for a country populated by individuals having identical tastes to choose free trade, then in the future to choose tariffs (or autarky) and then, in the more distant future to once again choose free trade, etc., raises some fundamental questions about the nature of the experiments conducted here. For instance, can one talk about a stationary (or steady) state in an environment which is institutionally (politically) unstable? If a

${ }^{1}$ It could just as easily have been supposed that $P$ increased with free trade so that in the future stationary state everyone would be better off than under autarky. The introduction of tariffs causing $P$ to fall would also be supported by a majority at that future time. 
majority gain from restricting trade can one really argue for free trade on welfare grounds knowing that compensation is virtually never made? Finally, is it possible to examine any question of economic policy without taking into account the past history and current institutional framework of an economy? I am not sure of the answers to any of these questions, but it appears that they are questions worthy of the economist's consideration. 


\section{References}

Cass, D. and M. E. Yaari, "Individual Saving, Aggregate Capital Accumulation and Efficient Growth," in Shel1, K., Essays on the Theory of Optimal Economic Growth, Massachusetts, The MIT Press, 1967.

Gale, D., "General Equilibrium with Imbalance of Trade," Journal of International Economics, May 1971, pp. 141-158。

Gale, D., "The Trade Imbalance Story," Journal of International Economics, May 1974, pp. 119-137.

Green, J., "The Question of Collective Rationality in Professor Gale's Model of Trade Imbalance," Journal of International Economics, February 1972, pp. 39-56。

Kareken, J. and N. Wallace, "Portfolio Autarky: A Welfare Analysis," Journal of International Economics, 1977, pp. 19-43.

Kemp, Mo, "The Gain from International Trade," Economic Journa1, December 1962, pP. 803-819

Kemp, $M_{0}$, The Pure Theory of International Trade and Investment, New Jersey, Prentice Ha11, 1969.

Samuelson, P. A., "The Gains from International Trade," Canadian Journal of Economics and Political Science, May 1939, Pp. 195-205.

Samuelson, P. A., "An Exact Consumption-Loan Model of Interest With or Without the Social Contrivance of Money," Journal of Political Economy, December 1958, pp。 467-482.

Samuelson, P. A., "The Gains from International Trade Once Again," Economic Journal, December 1962, PP. 820-829.

Stolper, W. F. and P. A. Samuelson, "Protection and Real Wages," Review of Economic Studies, November 1941, PP. 58-73。

Yaari, M. E., "On the Consumer's Lifetime Allocation Process," International Economic Review, September 1964, pp. 304-317. 